\title{
Александр Иванович Введенский как логик. Часть I
}

\author{
Б. В.Бирюков, Л. Г. БирюковА
}

\begin{abstract}
The paper is devoted to the logical ideas and the biography of the promonent Russian thinker Alexander Ivanovich Vvedenskiy (18561925).

Ключевые слова: А.И. Введенский, история логики, философская логика
\end{abstract}

Александр Иванович Введенский (1856-1925) - выдающийся русский философ и религиовед, занимавшийся также логикой и психологией. А.И. учился на математических факультетах университетов Москвы и Петербурга, окончил историко-филологический факультет Петербургского университета, где был учеником М.И. Владиславлева; именно под его руководством он прошел специализацию по философии.

Здесь необходимо сказать несколько слов о Михаиле Ивановиче Владиславлеве. Это был выдающийся русский мыслитель и деятельный участник развития высшего образования в России (в конце 80-х годов он занимал пост ректора Санкт-Петербургского университета). Владиславлев был хорошо знаком с зарубежной философией, так как три года находился в научной командировке за границей, где слушал таких мыслителей, как Куно Фишер и Лотце. В Петербурге Владиславлев читал лекции по логике, психологии и истории философии, вел, как сказали бы мы теперь, спецсеминар по изучению Аристотеля, в частности его «Метафизики» (по греческому оригиналу), и Канта (его «Критики чистого разума») и другим историко-философским темам. Введенскому было у кого учиться!

Владиславлев скончался в 1890 году, и А.И. Введенский посвятил своему учителю проникновенную статью [11]. 
В 1881 году А.И. Введенский окончил университет и был оставлен там «для приготовления к профессорскому званию». После магистерского экзамена был на два года командирован заграницу, в Германию, где в Гейдельберге слушал лекции Куно Фишера. Магистерскую диссертацию А.И. Введенский защитил в 1888 году. Она носила название «Опыт построения теории материи на принципах критической философии». В ней он проявил себя как сторонник философии Канта «критического» периода. И на протяжении всей своей научно-философской деятельности оставался верным кантианцем, разработавшим, однако, оригинальную концепцию «философского критицизма», которую он в конце своей научно-философской деятельности назвал «логицизмом».

Профессор философии столичного университета с 1890 года, где Введенский сменил скончавшегося М.И. Владиславлева, он читал лекции по логике, по философской мысли Античности и по истории философии в Новое время, а также по психологии. Читал он не только в университете, но и на Высших женских курсах и в Военно-юридической академии ${ }^{1}$.

Распространенная в России с конца XIX века в образованном обществе юношеская революционность не обошла и Введенского. Он принял участие в студенческих волнениях, и в 1879 г. полгода провел в заключении в Петропавловской крепости. Однако заступничество K. Бестужева-Рюмина ${ }^{2}$ (одного из учителей Введенского) и М. Владиславлева уберегло его от высылки из столицы. Но Александр Введенский быстро образумился, и в бурном 1905 г., будучи профессором столичного университета, уже выступал против политизации университетской жизни участия студентов в митингах и демонстрация ${ }^{3}$.

В конце 40 - начале 50-х годов Б.В. Бирюкову довелось быть преподавателем логики и истории в 1-м Московском городском

\footnotetext{
${ }^{1}$ О Введенском см.: [20, с. 226-236], [1, с. 171-172], [26].

${ }^{2}$ Константин Николаевич Бестужев-Рюмин (1829-1897) - историк, действительный член Петербургской Академии наук. Когда в столице в 1878 г. под его руководством были созданы Высшие женские курсы (так называемые Бестужевские), А.В. Введенский был привлечен для чтения на них лекций по логике.

ЗЭтими сведениями я обязан письменным сообщениям В.И.Кобзаря, в частности его письму от 8.09.2004 г.
} 
педагогическом училище. В нем моим коллегой был Николай Васильевич Румянцев, в прошлом член «Союза воинствующих безбожников» и автор большого труда о возникновении христианства, где пытался доказать неисторичность Христа как личности. Он рассказывал (считая, что логику это интересно) о том, что, будучи студентом Петербургского (или тогда уже Петроградского?) университета, слушал логические лекции Введенского.

Имя Введенского было широко известно в научных и культурных кругах столицы. Читал Александр Иванович замечательно, его лекции были очень яркими, аудитория всегда переполнена, послушать Введенского приходили студенты других факультетов. Этот рассказ находит подтверждение у В.В. Зеньковского, писавшего, что А.И. был «человеком острого ума, очень четкой и ясной мысли, большого литературного дарования»; он был «на редкость интересным мыслителем» [20, с. 226-227], и у Н.О. Лосского, отмечавшего, что А.И. обладал исключительным талантом педагога.

Введенский был автором гимназического учебника логики, удостоенного «полной большой премии Императора Петра Великого» $[7]^{4}$. В отчете Ученого Комитета о присуждении премий в 1910 году об этом учебнике, в частности, сказано, что в изложении профессора Введенского «логика получает характер удивительной связности, последовательности и принудительности», что у него даются «превосходные разъяснения логических явлений, которых мы не встречаем в других учебниках» ${ }^{5}$.

Любопытно было узнать от Румянцева некоторые чисто человеческие черты этой замечательной личности.

А.И. Введенский имел обыкновение опаздывать на лекции и экзамены, засиживался в ресторане, всегда у одного и того же столика близ окна, и это было известно студентам. Чтобы напомнить ему о себе, они водружали на трость форменную студенческую фуражку и поднимали ее на уровень окна, давая знать, что ждут своего профессора. Александр Иванович был непрочь

\footnotetext{
${ }^{4}$ Мне было доступно второе издание (СПб, 1913), на титульном листе которого значилось, что она удостоена указанной премии.

5 Эти слова можно найти на последней - рекламной - странице «Логики, как части теории познания» 1917 года издания.
} 
ударить за молодыми девицами, и однажды случился конфуз, когда предметом его ухаживаний - по словам Румянцева, довольно невинных - оказалась его слушательница на Высших женских курсах, где он читал лекции.

С книгой А.И. Введенского я познакомился в 50-х годах прошлого века, и из всех книг по философской логике, которых тогда было уже немало, книга А.И. Введенского о логике как составной части гносеологии, оставляла сильное не только интеллектуальное, но и эмоциональное впечатление. Конечно, это была книга по традиционной логике, а не по логике математической, с которой я тогда был незнаком. Теперь я понимаю, что учитъся логике по ней невозможно. Но целый ряд заключенных в ней идей не устарел. А сам труд без всякого сомнения принадлежит истории русской культуры.

Мы начнем с рассказа о том, как создавалось главное философско-логическое сочинение А.И. Введенского - его труд «Логика, как часть теории познания».

Первое издание «Логики» Введенского вышло в 1909 году. Как пишет автор в Предисловии к этой книге, чтение лекций по логике убедило его в том, что соответствующий лекционный курс приобретает единство и заинтересовывает слушателей лишь тогда, когда в нем присутствуют философские вопросы. Поэтому автор не только обогатил свой текст рассмотрением узловых проблем «критической» гносеологии, но и ввел термин «теория познания» в название своей книги.

В Предисловии ко 2-му изданию [8, с. V], вышедшему в 1912 году, А.И. сообщал, что издание 1909 года представляло собой исправленные лектором записи его лекций, составленных курсистками и студентами. Во втором же издании, пишет Введенский, «почти все написано мной самим».

Третье издание вышло через пять лет, в 1917 году. В Предисловии к нему автор писал, что это «почти новая книга». Главное изменение, по словам А.И., состояло в разработке «логицизма, как особого гносеологического направления» [9, с. III]. И, действительно, в третьем издании усилена теоретико-познавательная компонента книги. Это проявлялось уже в компоновке 
обеих книг. Книга 1912 года завершалась главой XX «Важнейшие частности в учении о категорических силлогизмах»; книга 1917-го - тремя чисто философскими главами, где излагался «логицизм А.И. Введенского», подвергался критике позитивизм, эмпиризм и рационализм и характеризовалось «цельное научнопереработанное мировоззрение»; изложение теолого-философских вопросов было расширено.

В начале 20-х годов «Логика» Введенского вышла четвертым изданием [10].

Логический труд Введенского 6 показывал, какие выводы для логики следуют из философии Канта «критического» периода, но больше - какие выводы для обоснования философского «критицизма» можно сделать на основании логики. В.В. Зеньковский считал, что, как неокантианец, Введенский по своим воззрениям близок Г. Когену. Однако он был вполне самостоятельным мыслителем. Следуя, в общем, учению Канта, он внес в «критическую» философию много оригинального, вытекавшего из его логического учения ${ }^{7}$.

Из «Логики» Введенского явствовало, что логика совершенно независима от других наук, в частности от психологии; что между «логикой открытия» новых истин и «логикой проверки» истин, уже установленных, следует проводить четкую грань. Анализируя познание, различая в нем априорную и апостериорную стороны, А.И. вместе с тем рассматривал метафизику как гипотетическое дополнение к знанию. Сопоставляя знание и веру, он с исключительной ясностью раскрывал сущность христианства.

Ниже мы выделим то, что представляется нам главным в логико-гносеологических и философско-теологических воззрениях Введенского.

\footnotetext{
${ }^{6}$ А.И. Введенскому принадлежит также книга «Психология без всякой метафизики» (я пользовался третьим, исправленным и дополненным изданием [17]).

${ }^{7}$ Страницы книги В.В. Зеньковского, отведенные философским взглядам Введенского, удивляют. Зарубежный русский историограф русской философии полностью игнорирует логическую основу трактовки Введенским кантовского «критицизма», что делает путаными многословные рассуждения Василия Васильевича о «критицизме» и метафизике, привязанные к воззрениям Александра Ивановича.
} 


\begin{abstract}
$* * *$
Первое, на что следует обратить внимание, это то, как Введенский понимал логику.

Логикою называется наука о правильности и ошибочности мышления. Правильным же называется мышление, пригодное для расширения знания, а ошибочным или неправильным - непригодное для этой цели. Задачи логики состоят в том, чтобы: 1) отыскать те правила или условия, при исполнении которых (будет ли оно преднамеренным или ненамеренным, это все равно) мышление выходит пригодным для расширения знания; 2) объяснить их законами мышления; 3) с помощью найденных ею правил выследить все те ошибки мышления (т.е. нарушения этих правил), которые встречаются в нем на деле, и описать их состав, т.е. указать, в чем состоит каждая из них $[9$, с. 1$]$.
\end{abstract}

Это - понимание логики, близкое к современному. Правда, в наше время, объясняя суть логики, обычно говорят не о мышлении, а о рассуждении - именно для того, чтобы предотвратить психологизацию логики, т.е. то, против чего восставал Введенский и о чем будет сказано далее. Представленное у Введенского разъяснение сущности логики - с точностью до одного акцента, о котором мы вскоре скажем, - достаточно близко к взгляду, который выработан в математической логике. Для нее обрисованная Введенским область знания составляет философскую логику. Чтобы не быть голословным, приведем воззрения на этот счет такого выдающегося современного математического логика и философа, как Хаскелл Б. Карри.

Карри присоединился к распространенному взгляду, что «логика есть анализ и критика мышления». Далее читаем:

Рассуждая, мы из некоторых исходных данных выводим заключения. Мы замечаем, что эти заключения иногда верны, а иногда нет, и что иногда (но не всегда) ошибочность заключений объясняется ошибоч- 
ностью некоторых из наших исходных данных. Постепенно мы убеждаемся, что на рассуждения, проводимые в согласии с определенными нормами, можно полагаться, если данные были правильными. Изучение такого рода норм, т.е. принципов правильного рассуждения, всегда считалась одной из задач философии [21, с. 17].

Так понимаемую логику Карри назвал философской логикой и отметил, что при ее изучении «оказалось полезным применять математические методы, т.е. строить математические системы, определенным образом связанные с логикой». Исследование таких систем составляет математическую логику. Философская и математическая логика тесно связаны между собой. Термином «логика» называют также конкретные системы или теории, являющиеся «предметом изучения математической или философской логики». Так, говорят о классической логике, модальной логике, аристотелевской логике, кантовской логике и пр. [21, c. $17-19]$.

Взгляды Введенского на логику в своем существе отвечают дефиниции, данной в статье «Логика» в Большой Советской Энциклопедии. Там логика определена как наука о приемлемых способах рассуждения [22]. Под этой, начальной, частью статьи стоит подпись М.М. Новоселова, но данная дефиниция «логики» возникла в ходе обсуждений и была принята А.А. Марковым ${ }^{8}$.

Стоит привести следующее затем разъяснение этого определения, которое дал М.М. Новоселов:

Слово «логика» в его современном употреблении многозначно, хотя и не столь богато смысловыми оттен-

\footnotetext{
8 Этот факт известен мне, так как я состоял научным консультантом по логике издательства «Советская Энциклопедия», выпускавшего БСЭ (этот факт отмечен в конце первого тома данного издания, где приведен список научных консультантов). Статья «Логика» состоит из ряда разделов. Первый из них - «История логики» подписан М.М. Новоселовым, 3.А. Кузичевой и Б.В. Бирюковым, второй, главный - «Предмет и методы современной логики» принадлежит Маркову; раздел «Научные учреждения и издания» - Кузичевой и Новоселову. В томе имеется серия статей о разных «логиках» - «Логика высказываний», «Логика предикатов» и др., в числе авторов которых были А.Г. Драгалин и Ю.А. Гастев.
} 
ками, как древнегреческое logos, от которого оно происходит. В духе традиции с понятием логики связываются три основных аспекта: онтологический - логика вещей, т.е. необходимая связь явлений объективного мира (Демокрит); гносеологический - «логика знания», т.е. необходимая связь понятий, посредством которых познается сущность и истина (Платон), и демонстративный (доказательный) или собственно логический - «логика доказательств и опровержений», т.е. необходимая связь суждений (высказываний) в рассуждениях (умозаключениях), принудительная убедительность («общезначимость») которых вытекает только из формы этой связи безотносительно к тому, выражают ли эти суждения «сущность и истину», или нет (Аристотель). Первые два аспекта относятся к философии и диалектической логике, последний же аспект составляет собственно логику или современную логику (которую вслед за Кантом иногда называют формальной логикой) [22].

Это разъяснение несомненно принял бы и Введенский. Для него термин «логика» соответствовал третьему из приведенных выше его значений ${ }^{9}$.

Правда, определяя логику, А.И. (см. приведенную цитату из книги 1917 года издания) упоминает ошибочность мышления и вообще слишком большое внимание уделяет способности нашей мысли сбиваться с логически правильных - и потому приемлемых - рассуждений. В издании 1912 года в объяснении того, что такое логика, упоминание «ошибочности» отсутствует.

Bторое положение заключалось в четком разграничении нормативного и описательного подхода к мышлению. Нормативная сторона изучается логикой, а именно «логикой проверки», описательная сторона составляет предмет психологии. Последняя изучает мышление безоценочным образом, «логика же рассматривает мышление, только оценивая годность каж-

\footnotetext{
${ }^{9}$ Забегая вперед, замечу, что оппонент Введенского - Н.О. Лосский объединял в своем учении - интуитивизме - все три приведенных выше значений.
} 
дого способа мышления для расширения знания» ${ }^{10}[8$, с. 6]. При этом логика не обязана объяснять, «что такое мышление, какова его природа, и каковы его отличия от деятельности памяти и воображения. Это - задача психологии, а не логики. При изучении же логики достаточно помнить, что переживания суждений и умозаключений всеми принято называть мышлением» $[9$, с. 7$]$.

Как нормативная дисциплина - наука о правильности мышления, - логика служит расширению знания; для этого в ней формулируются нормы правильного хода мысли, позволяющие отделять его от ошибочного рассуждения. Выявляя те правила, при которых заключение находится в логической связи с посылками, логика вместе с тем описывает умозаключения, которые ошибочны, «но имеют свойство казаться правильными» [8, с. 9]; именно в этом пункте психология особенно зависит от логики, основывается на предварительном ее изучении.

Будучи совершенно не зависимой от психологии, изучающей мышление безоценочно, как факт, логика рассматривает его только с той точки зрения, годен или нет для приращения знания тот или иной способ мышления. Этот взгляд был четким выражением логического антипсихологизма. Заметим, что Введенский ссылался здесь на Э. Гуссерля, который, по словам А.И., опроверг «разнообразные ухищрения, которыми хотят оправдать психологизм в логике» ${ }^{11}$ [8, с. 15]. Правда, сам А.И. признавал, что логика и психология «соприкасаются между собою», причем, как сказано выше, особенно тесно при рассмотрении ошибочных умозаключений.

Эти представления Введенского о логике отвечают сути дела - за одним исключением: то внимание, которое он уделяет ошибочному мышлению, не свойственно современной логике.

Взгляд на отношение логики к гносеологии составляет третъе положение. Как следует из названия книги, логика, соглас-

\footnotetext{
${ }^{10}$ Приведенные слова набраны в книге курсивом. Вообще все издания «Логики» Введенского пестрят курсивом; им набраны целые фразы, а иногда и большие куски текста. Я не стану воспроизводить эту манеру выделения авторской мысли.

${ }^{11}$ Подстрочное примечание. Введенский имеет в виду русский перевод книги Гуссерля «Логические исследования» (ч. 1; СПб., 1909), выполненный С.Л. Франком.
} 
но Введенскому, составляет часть теории познания, причем такую часть, которая предшествует основному содержанию этой теории. Логика «оказывается независимой от гносеологии и не имеет права основываться на ней» [9, с. 5]. Здесь - как и во многом другом - Введенский полемизировал с Н.О. Лосским; он решительно отвергал его мнение, будто логика основывается на теории познания ${ }^{12}$.

Это совершенно верное понимание сути дела. Ни философская, ни математическая логика не предполагают никаких предварительных гносеологических установок. Введенский, следуя идеям Канта, подчеркивал, что логика «должна вести все свои исследования без всяких произвольных предпосылок», к которым он относил метафизические представления об «истинном бытии». Он разворачивал это положение в виде противопоставления трансцендентных и имманентных предметов. Первые это такие предметы, которые «никогда и нигде и ни при каком изощрении наших способностей» не могут стать объектом знания - находятся за пределами всякого возможного опыта. Вторые - имманентные предметы - воспринимаются (или могли бы восприниматься) нами в опыте. Изучение - точнее попытка изучения - трансцендентных предметов «относится к так называемой метафизике», или учению об «истинном бытии» $[9$, c. 28-30]. Ее главные задачи сводятся к трем следующим вопроcaм:

- «Составляет ли истинное бытие, т.е. вещи в себе, то же самое, что и данные опыта, или же оно отличается от них?»

- «Если оно не то же самое, что данные опыта, то каково же оно: в чем сходство и разница между вещами в себе и данными опыта, т.е. между истинным (ноуменальным) и кажущимся (феноменальным) бытием?»

- А в этих двух вопросах, очевидно, заключается еще и такой: «входят ли в состав истинного

\footnotetext{
12 Этот взгляд был высказан Лосским в его брошюре «Логика проф. А.И. Введенского» (СПб., 1912), перед этим напечатанной в виде статьи в журнале «Вопросы философии и психологии». О полемике Введенского с Лосским у нас еще будет речь.
} 
бытия, иначе - вещей в себе, также и трансцендентные предметы; или же нет никаких трансцендентных предметов, а всякое бытие имманентно, хотя бы и воспринималось нами не вполне в том самом виде, как оно существует в действительности, а в кажущемся (феноменальном)?» [9, c. 32].

Метафизика должна быть наукой об «истинном бытии», о вещах в себе, и именно потому ей приходится быть и наукой о трансцендентных предметах, к которым, в частности, принадлежат душа и Бог. Все трансцендентное оказывается метафизическим; «но метафизическое, может быть, еще не все окажется трансцендентным»; поэтому вопрос о возможности знания трансцендентных предметов - трансцендентного знания приводит к вопросу о возможности метафизики вообще.

Для логики как первоначальной части гносеологии безразличен вопрос о возможности знания об истинном бытии.

Четвертое положение состоит в утверждении необходимости четкого разграничения веры и знания.

Как пишет Введенский, разделение мыслей, сопровождаемых уверенностью в их истинности, на знание и веру, возникло еще до появления логики. Но коль скоро она возникла, ее обязанностью стало указание, «каким требованиям должны удовлетворять мысли, в истинности которых мы уверены, чтобы они имели право считаться знанием» $[9$, с. 14]. Изучение же знания как такового составляет задачу философии. На ней лежит обязанность выяснить те условия, благодаря которым существует бесспорно признаваемое знание и до каких границ оно может простираться, так что, перейдя их, мы попадаем в область, «в которой возможны лишь одинаково доказуемые и одинаково неопровержимые мнения, т.е. вера, а не знание» [9, с. 25]. Знанием являются математика и естественные науки, но также психология, история, лингвистика и пр., «словом - всякое изучение данных опыта, производимое независимо от того, считается ли оно истинным или кажущимся бытием» [9, с. 36].

Нам представляется, что мы должны присоединиться к этому взгляду в его общем виде, когда к области веры относят все, касающееся религиозных представлений, в России - православия. 
Вместе с тем мы должны оставить за наукой право проверять явления, относительно реальности которых у ученых существуют разные мнения; такими, например, являются те, которые известны под названием телепатии и ясновидения.

Пятое положение касается противопоставления, говоря языком Введенского, «логики проверки» и «логики открытия». Согласно его взгляду, «логики открытий» не существует, имеется только логика, позволяющая проверять правильность уже состоявшихся рассуждений. Логика, указывающая как открывать новое, - это еще не реализованный замысел. Правда, результаты логики имеют определенное эвристическое значение: они предохраняют от того, чтобы принимать «за годные» такие умозаключения и доказательства, которые неправильны. Но этим их эвристичность и ограничивается. Логических правил, соблюдение которых приводило бы к новым истинам, нет, хотя начиная с IV века многие мыслители пытались их обнаружить, здесь Введенский называет имена Раймунда Луллия, Джордано Бруно, Френсиса Бэкона, - но настоящего успеха их усилия не принесли. Поэтому А.И. и утверждает, что в наличии имеется только логика проверки уже открытых истин, пусть они присутствуют лишь в форме догадок, научных гипотез (которые, согласно Введенскому, еще нельзя относить к знанию); «логика всегда предполагает, что догадка уже возникла, и ведет речь только о том, как ее проверить» $[9$, с. 3]. Вместе с тем: «Хотя логика совершенно бесполезна в смысле руководства к усвоению искусства правильно мыслить, она $<\ldots>$ служит руководством в критике проявлений этого искусства» [5, с. 22].

Этот взгляд Введенского согласовался с установками математической логики, но лишь в докибернетический период ее развития. С началом работ по алгоритмизации и компьютеризации поиска логического вывода ситуация стала меняться ${ }^{13}$. Ныне логическая эвристика представлена в активно ведущихся работах по «искусственному интеллекту» ${ }^{14}$.

В философской логике времен Введенского преобладала традиция излагать ее по схеме «понятие - суждение - умозаключение - доказательство». Именно так представлена логика в учеб-

\footnotetext{
${ }^{13}$ См. хотя бы: [3].

${ }^{14} \mathrm{Cm}$, например, [28].
} 
нике Г.И.Челпанова ${ }^{15}$ [29], по которому после 1946 года учились поколения советских философов. Введенский не следует этой схеме. Он начинает изложение логики - и в этом заключается шестое выделяемое нами положение - с суждений. Он поступает так потому, что знание состоит из суждений; «другие мысли - понятия, представления и т.п. - входят в состав знания лишь постольку, поскольку они служат составными частями суждений» [9, с. 7]; только суждения могут быть носителями истины и из соединения суждений возникают умозаключения. Поэтому разбор суждений предшествует у Введенского рассмотрению понятий.

Это совершенно верный взгляд. Развертывание систем современной философской или математической логики начинается всегда с рассмотрения суждений, или высказываний, которое в случае математизации логики приобретает форму индуктивного определения понятия формулы как выражения, которое может быть истинным либо ложным. Кроме того изложение логики высказываний предшествует изложению логики предикатов, т.е. понятий.

Фундаментальной категорией логики является понятие логического следования заключения из посылок. В «Логике как части теории познания» присутствует совершенно четкое представление о логическом следовании (это седъмое положение, выделяемое нами у Введенского). В этой книге оно выступает как свойство (правильных) умозаключений принуждать, принимая посылки, принимать и заключение («вывод», как чаще говорил А.И.):

Про вывод правильных умозаключений в логике принято говорить, что вывод в них вытекает, или следует, или получается из посылок. Про вывод же неправильных принято говорить, что вывод в них не вытекает, не следует, не получается из посылок [9, c. 9].

\footnotetext{
15Этот учебник неоднократно переиздавался, в 1918 г. вышло его 10-е издание; в 1946 г. он был издан в сокращенном виде (вызванном идеологическими соображениями); переиздан в своем подлинном виде в 1994 г. В настоящее время готовится его новое издание, предваряемое статьей о Челпанове, написанном автором этих строк.
} 
В первом случае связь вывода с посылками называется логической, потому что она определяется «логическими законами мышления» [9, с. 9].

Это был бы совершенно верный взгляд, если бы понимание Введенским «логических законов», а также того, какую роль они играют в логическом следовании, не ограничивалось четырьмя известными в традиционной логике законами - противоречия, исключенного третьего, тождества и достаточного основания. В современной логике последний из названных законов вообще всерьез не рассматривается (он неявно входит в понятие доказательства), а понятие закона логики распространяется на любые тождественно-истинные высказывания, или высказывания, доказуемые из пустого множества посылок. Что касается законов противоречия, исключенного третьего и тождества, то они действительно занимают в современной логике - как математической, так и философской - особое место. Это объясняется тем, что решение проблемы сохранения, ограничения, ослабления или даже отказа от того или другого из них влечет серию «неклассических» направлений в исследовании дискурсивного знания и потому приобретает фундаментальную значимость в математико-логических и философско-математических рассмотрениях.

Высокая оценка познавательной роли обобщений, точнее, общих суждений, составляет восъмое положение. В знании, считал Введенский, наибольшее значение следует придавать именно им, так как констатация общего позволяет предсказывать ход изучаемых явлений. Все математические теоремы, писал он, представляют собой общие суждения. Они - «подлинно общие», как утверждал А.И., отличая от подлинно общих суждения, только кажущиеся общими. Под последними он имел в виду суждения, относящиеся к строго определенному, хотя бы и очень большому числу предметов (в традиционной логике такие суждения называют регистрирующими). Таково приводимое Введенским суждение «Все апостолы родом из Галилеи» - его можно заменить двенадцатью следующими единичными суждениями: «Апостол Андрей родом из Галилеи», «Апостол Петр тоже», «Апостол Фома - тоже» и т.д. Таким образом, суждение о том, что все апостолы были родом из Галилеи, является 
«всего лишь суммирующим соединением нескольких единичных суждений. Что касается подлинно общих суждений, то каждое из них относится к бесконечно большому числу предметов» $[9$, c. 111]; следует заметить, что «бесконечное» А.И. понимал здесь не только в математическом смысле, но и как неограниченно большое.

Примечательно, что тезис о наибольшей познавательной значимости общих суждений А.И. распространял и на историческую науку, отвергая отстаивавшееся немецкими неокантианцами В. Виндельбандом и Г. Риккертом противопоставление номотетических («законоустанавливающих») наук, коими являются науки естественные, наукам идеографическим («единичноописывающим»), к которым принадлежит история. Согласно Введенскому, историческая наука должна иметь смысл, «а не быть всего только „интересной“» [8, с. 90], как считали немецкие неокантианцы. И нет сомнения в том, что в этом с ним следует согласиться.

Введенский, безусловно, прав, подчеркивая высокую познавательную роль обобщений. Однако его противопоставление общих суждений частным требует коррективов. Дело в том, что обобщающее знание может передаваться и частными суждениями, если надлежащим образом использовать операцию отрицания. Ведь для передачи мысли, выраженной в общем (утвердительном) суждении (суждении вида $a$, как его принято обозначать в категорической силлогистике), мы можем воспользоваться известным «логическим квадратом»- подвергнуть отриианию суждение типа $o$ - частно-отрицательное: «Некоторые $S$ не суть $P$ » и тем самым выразить ту же мысль, что и суждение «Все $S$ суть $P »$ (оговорив при этом, что квантор некоторые понимается в смысле «некоторые, а может быть и все»). Эта взаимосвязь общего и частного четко видна и из взаимовыразимости кванторов общности и существования в математической логике. Суждение вида $\forall x P(x)$ - «Для всех предметов х (рассматриваемой предметной области) верно, что они имеют свойство $P \gg$ равносильно суждению вида $\neg \exists x(\neg P(x))-\ll$ Не существует такого предмета $x$, который не имел бы свойства $P$ ». Здесь суждения существования соответствуют частным суждениям.

Вполне современна и мысль А.И. относительно необходимо- 
сти рассмотрения аналитических суждений (девятое положение). Правда, их рассмотрение у него основывается на «критическом» взгляде на познание. Здесь он следует не Лейбницу (что сделало бы его взгляды более убедительными), а Канту. Исходя из субъектно-предикатной структуры суждений традиционной логики и следуя создателю «Критики чистого разума», Введенский соответствующим образом истолковывает различие между аналитическими и синтетическими суждениями. В случае первых «расчленение», или анализ, содержания подлежащего (субъекта) позволяет обнаружить в нем все признаки сказуемого (предиката), в то время как для синтетических суждений подобный анализ обнаруживает в последнем признаки, которых нет в субъекте. В силу этого «относительно каждого синтетического суждения мы имеем полное право сомневаться, следует ли допускать в знании именно это суждение или же одно из противоположных с ним. Поэтому не может быть никакой явной нелепости сомневаться в любой математической $<\ldots>$ аксиоме» [8, с. 143]. И Александр Иванович приводит в связи с этим выдвинутое Н.И. Лобачевским суждение, являющееся противоположным по отношению к «одиннадцатой аксиоме Эвклида» (ныне обычно называемой пятым постулатом Евклида), которое позволило русскому математику «построить полную систему геометрии, которая нигде не запутывается в противоречиях, т.е. оказывается не менее возможной и мыслимой, а потому и не менее допустимой, чем геометрия Эвклида» [8, с. 144].

Знание расширяется только с помощью синтетических суждений - аналитические служат лишь разъяснению содержания своих субъектов. При этом науки, «не соединенные с установкой данных опыта», как говорил А.И., - математика прежде всего требуют, чтобы в их «высших основаниях» имелись такие суждения, которые были бы и синтетическими, и внеопытыми, или априорными (априорность при этом, как подчеркивал А.И., не следует понимать как врожденность).

Математическая логика, а также развитие связанных с ней философских идей, привели к выводу, что аналитичность суждений можно - и нужно - понимать более общо, чем это было у Канта (и Введенского): относить к аналитическим любые суждения, истинность которых устанавливается путем анализа ча- 
стей, их составляющих, без обращения к каким-либо внелогическим данным. Тогда у истоков теории аналитических суждений оказывается Лейбниц.

Следующее, десятое, положение заключалось в том мотиве, который двигал Введенским, когда он решительно отстаивал силлогистику как то главное в логике, что позволяет отличать в мышлении его правильный ход и отвергать неправильный. Мотив этот заключался для А.И. в способности выражать процесс движения мысли, приводящий к расширению знания, а эту способность он представлял себе в виде силлогистического процесса. Правда, «силлогизм» для него был не только ассерторическим, а любым умозаключением дедуктивной логики, лишь бы оно из истинных посылок приводило к верному заключению (выводу).

Здесь стоит сказать, что Введенский был способен вникать в тонкие вопросы логики. Об этом свидетельствует его работа, в которой обосновывался взгляд, что все четыре фигуры ассерторической силлогистики самостоятельны [12]. Ассерторическая силлогистика рассматривалась им с разных точек зрения - практической, абстрактно-логической, абстрактнопсихологической и гносеологической. Он показывал, что с абстрактно-логической точки зрения вопрос о числе самостоятельных фигур «упраздняется; они все сводимы друг на друга». Здесь у читателя, знакомого с логикой, может возникнуть вопрос, как это возможно, если, например, по третьей фигуре заключения всех ее модусов должны быть частными. Вопрос решается просто: при сведении модусов одной фигуры к модусам другой используются непосредственные умозаключения - превращение суждений, их обращение и пр. Что касается очевидноcmu силлогистических умозаключений, то Введенский рассуждал следующим образом:

Рассматривая силлогизмы с логической стороны, мы можем иметь в виду не их самих, но оценку убедительности [их как] доказательств. Поэтому и вопрос о самостоятельности фигур, при такой точке зрения, мы должны поставить в следующей форме: какие из фигур окажутся самостоятельными, если под словом «самостоятельность» подразумевать, что 
вывод вытекает из посылок вполне очевидным образом? Или - другими словами: во всех ли фигурах вывод отличается одинаково полной очевидностью? Такой вопрос и имел в виду Аристотель, когда характеризовал первую фигуру как совершенную, а вторую и третью как несовершенные. Четвертой же фигуры, как известно, он не рассматривал. При помощи самого простого самонаблюдения легко убедиться, что первые три фигуры отличаются вполне одинаковой очевидностью [12, с. $124-125$ (с. 6-7 оттиска)].

Аристотелевские фигуры (с первой по третью), указывал Введенский, имеют явное и одинаковое преимущество перед четвертой как более естественные и дающие более очевидные выводы. Завершаются же рассуждения А.И. о силлогизмах следующими проницательными словами: «факт сводимости фигур показывает, что если рассматривать силлогизмы как чисто умственные процессы, без всякого отношения к речи, то в них нет никаких фигур» [12, с. 130 (с. 12 оттиска)] (!).

Теперь о математизации логики. С ней А.И. был в известной мере знаком, но считал, что для представления логического мышления она ничего дать не может. Здесь он, в целом, ошибался. Достаточно вдуматься в историю логики, включая математическую, которая составляет исходный пункт развиваемой в рамках «искусственного интеллекта» логической эвристики, чтобы понять, что взгляды автора труда «Логика как часть теории познания» в этом пункте несостоятельны.

Но «анти-математическая» убежденность Введенского в известном смысле была оправданна. Подавляющая часть логических исчислений - потенциально бесконечных по своему «количеству» (которое может быть мощности континуум!) - действительно бесполезна для обогащения знания и тем более для уяснения мыслительной деятельности, к этому приращению приводящей.

А.И. Введенский считал, что им дано «Новое и легкое доказательство философского критицизма». Доказательство это было изложено в докладе, представленном Санкт-Петербургскому 
Философскому обществу на заседании 7 ноября 1908 года, и сразу же опубликовано в виде статьи под тем же названием [13, с. 122-144]; в 1909 году эта статья была выпущена в виде отдельного оттиска ${ }^{16}[14]$.

Доказательство «критицизма» в смысле Канта было у Введенского основано на описанной выше его концепции логики и потому получило - в книгах 1917 и 1922 годов - название «логицизма». Так как этот термин в настоящее время «занят» за другим смыслом (им обозначают восходящую к Готтлобу Фреге, но в полной мере представленную у Бертрана Рассела концепцию сведения математики к логике), мы будем называть концепцию А.И. - «логицизмом Введенского» (это тем более уместно, что сам автор так ее и именовал).

«Логицизм Введенского» подробно изложен в его книге 1917 года. По убеждению А.И., его логицизм покоился прежде всего на законе противоречия (а вместе с ним и на законах тождества и исключенного третьего). Для прояснения смысла соответствующих рассуждений, представленных в книге «Логика как часть теории познания» 1917 года, мы воспользуемся упомянутым оттиском его статьи 1909 года, а также изложением его взглядов, которое было дано В.В. Зеньковским [20, с. 229-232].

Введенский ставит вопрос: каковы логические законы мышления: естественные или нормативные? На этот вопрос обыкновенно отвечают, сразу имея в виду все четыре закона: «либо их все вместе считают естественными, либо все вместе нормативными $\langle\ldots>$ В действительности же они отчасти естественные, а отчасти нормативные». В законе исключенного третьего А.И. усматривал «все признаки естественного закона», так как он «высказывает чисто естественную неспособность нашего мышления придумать, или создать и мыслить такое третье отношение, которое не было бы ни утвердительным, ни отрицательным» $[14$, с. 6-10].

Мы знаем, что такое «третье отношение» возможно - в виде соединения утверждения и отрицания (как и поступил современник Введенского - Н.А. Васильев), но оно для А.И. запрещается законом противоречия. Для Введенского это - самый

\footnotetext{
${ }^{16}$ На обороте титульного листа оттиска указывалось: извлечено из Журнала Министерства Народного просвещения за 1909 год.
} 
важный закон, и А.И. утверждает, что он «мог бы даже ограничиться лишь рассмотрением этого закона, не говоря ни слова о трех остальных» - в нем «центральный пункт» всех его соображений.

Закон противоречия, который, говорил Введенский, было бы лучше называть законом непротиворечия или даже законом невозможности противоречия, носит двойственный характер. С одной стороны, он кажется чисто естественным законом, «потому что мы не в силах представить себе противоречие осуществленным. $<\ldots>$ Но с другой стороны, он кажется и чисто нормативным. Ведь известно, что нам приходится стараться избегать противоречия в своих мыслях» [14, с. 10]. Эту двойственность Введенский объяснял различием, существующим между представлениями и мышлением: закон противоречия «естественен» для наших представлений и «нормативен» для нашего мышления. Противоречие непредставимо, но мыслимо [14, с. 11-13].

Чисто естественным, по Введенскому, является закон тождества. Это объясняется тем, что мышление невозможно, если не производить отождествления каждой мысли с ней самой. Что касается закона достаточного основания, то, по Введенскому, он только нормативен. «Как закон мышления, т.е. в своей логической форме, когда его не смешивают $<\ldots>$ с законом причинности, он предписывает, чтобы мы не соглашались ни с одной мыслью, для которой у нас нет основания, достаточного для того, чтобы принудить нас согласиться с ней» [14, с. 8].

Согласно Введенскому, логические умозаключения, которые основаны прежде всего на законе противоречия, неуместны в отношении того, что находится за пределами логики, то есть для «вещей в себе». Но, комментирует В.В. Зеньковский воззрения А.И., быть заключенным в мире явлений невыносимо, и апостериорное знание и философское мышление стремятся вывести нас за его пределы, в трансцендентный мир.

В одном из последних разделов своего доклада (статьи) «Новое и легкое доказательство философского критицизма», озаглавленного «Единственное средство для спасения метафизики в виде знания», Введенский ставит вопрос: а нельзя ли спасти метафизику как знание о трансцендентном мире посредством учения, допускающего, что к нему возможен непосредственный 
доступ? Его ответ гласит: с помощью допущения, что мы обладаем «способностью прямо, непосредственно, т.е. без всякой помощи умозаключений, усматривать вещи в себе, вроде того, как это говорят мистицизм и интуитивизм, мы не спасем метафизики в виде знания. Подлинное постижение такого рода трансцендентного мира дается только верой».

Неудивительно, поэтому, что возникают требования изгнать из науки понятие о вещи в себе как противоречивого понятия. А.И. пишет:

В понятии вещи в себе подразумевается задача мыслить бытие, независимое от нас, от переживаний нашего сознания, а потому и независимое от логических законов мышления, между тем мы можем мыслить что бы то ни было не иначе, как в подчинении естественным законам мышления [14, с. 24].

Но тогда возникает проблема, «какая польза для науки из понятия вещей в себе, коль скоро о них нельзя знать ровно ничего, даже и того, существуют они или нет, а если существуют, то подчиняются ли логическим законам мышления или не подчиняются». Решение этой проблемы, говорит Введенский, указал уже Кант: это понятие указывает на границу логически позволительного применения причинности и других категорий. $\mathrm{K}$ этому кантовскому положению Введенский добавляет, что благодаря этому понятию обнаруживается граница «логически позволительного» использования умозаключений - оно ограничивается лишь явлениями. При такой позиции понятно, что Введенский отвергал и диалектику Гегеля, и метафизику Фихте и Шеллинга.

Таков был развивавшийся Введенским взгляд на проблему применимости к трансцендентному миру - «истинному бытию» - законов логики. Заметим, что это была проблема, которую рассматривали многие русские мыслители конца XIX - начала XX века, в частности ученик и современник А.И. И.И. Лапшин. А Н.А. Васильева, как мы уже говорили, проблема эта привела к мысли о неаристотелевой логике. Сам Введенский считал, что мы можем ясно мыслить «то, что не можем представить, хотя бы и смутным образом» [8, с. 250]. По его 
мнению, апостол Павел «уже чувствовал, что сама же логика требует считать неизвестным, все ли подчинено закону противоречия, и в частности - подчинен ли ему Бог» [10, с. 349]. Эта ситуация означает, что пользоваться умозаключениями и доказательствами «уместно и логически позволительно только в применении к таким предметам, относительно которых мы уже знаем, что они подчиняются закону противоречия» [8, с. 262]. Что касается «истинного бытия», то есть вещей в себе, то у нас нет никаких средств удостовериться, подчиняются они или не подчиняются этому закону.

Когда Введенский оставлял открытым данный вопрос, кажется, будто он допускал построение «логики противоречия». Однако это не так. А.И. писал, что если о предметах не известно, подчиняются ли они закону противоречия, то для них «ни из каких посылок не вытекает ровно никаких выводов» $[8$, c. 262]. Но уже тогда Н.А. Васильев построил свою «воображаемую логику», в которой допускаются суждения, содержащие в себе противоречия. Заметим, что в нашей домашней библиотеке имелся экземпляр журнала, в котором была напечатана одна из главных статей Н.А. Васильева, в которой не только излагались положения его «логики противоречия», но и обсуждались те логико-онтологические проблемы, которые поднимал Введенский [4]. Но, читая эту статью в 50-х годах прошлого века, не просто было усмотреть связь между идеями Васильева и Введенского и оценить логическое новаторство казанского ученого ${ }^{17}$.

K этому можно добавить, что тогда же, в первые десятилетия прошлого века, воззрение о противоречивости - антиномичности богословской Истины отстаивал о. Павел Флоренский.

$$
* * *
$$

Для понимания того, как «критицизм» Введенского преломлялся при решении конкретных философских вопросов, расскажем о двух из них. Первый представлен работой о пределах и признаках одушевления, т.е. говоря современным языком - пси-

\footnotetext{
${ }^{17}$ Спустя примерно десять лет на концепцию Н.А. Васильева обратил внимание В.А. Смирнов [27].
} 
хики $[16]^{18}$, второй - публичной лекцией на тему «Спор о свободе воли перед судом критической философии», которую А.И. прочитал в актовом зале Санкт-Петербургских Высших женских курсов 25 марта 1900 года [18].

В работе «О пределах и признаках одушевления» Введенский сформулировал «новый психо-физический закон», ставя его в связь с вопросом о возможности метафизики. В работе обосновывался взгляд, согласно которому вопрос о пределах одушевления принадлежит к числу эмпирически неразрешимых.

Нужно сказать, что эта работа Введенского особенно привлекла наше внимание в связи с вопросом о сущности психики. Продумывая вопрос о предмете этой науки, мы обнаружили, что центральное ее понятие - понятие о психике ускользает от определения, и ученым-психологам не остается ничего другого, как ссылаться на то, что психические явления знакомы каждому человеку по его собственному опыту. Если бы тогда нам была известна работа Введенского, стало бы понятно, что это не случайно - объективных признаков, позволяющих определить, обладает ли данное живое существо психикой или нет, не существует.

Но вернемся к Введенскому. Он начал свою работу так:

Настоящее исследование относится к области критической философии. Поэтому оно ведется в предположении неразрешимости одними теоретическими путями таких вопросов, как, например, о смысле мироздания, одна ли материя порождает душевную жизнь, или же, наоборот, первая сама является существующей только благодаря существованию сознания, а без него ее не было бы, и т.п., словом, в предположении неразрешимости всех вопросов, выходящих за пределы возможного опыта [16, с. 3$]$.

Далее Введенский отверг взгляд, согласно которому вопрос об объективных признаках одушевления (и убеждение в существовании чужой душевной жизни) решается путем просто-

\footnotetext{
${ }^{18}$ На обороте титульного листа значится: Извлечено из Журнала Министерства Народного Просвещения за 1892 г.
} 
го умозаключения по аналогии (будто бы мы от внешнего сходства переходим к внутреннему). Окончательный вывод, вытекающий из проведенного им исследования, он видел в следующем:

... если признать убеждение в существовании чужой душевной жизни за достоверную истину, и притом такую истину, которая не просто принята на веру, а проверена нами, то надо допустить, что, сверх внешних чувств и обсуждающего их показания ума, у нас есть еще особый орган, доставляющий нам сведения о том, что находится вне нас (мы его называем метафизическим чувством); в противном случае придется или считать убеждение в существовании чужой душевной жизни недостоверным и недоказуемым, или же возвратиться к какой-либо столь же недостоверной и недоказуемой системе старинной метафизики (к материализму или спиритуализму, это будет зависеть от личного вкуса) [16, с. 3-4].

Введенский указывал на тот факт, что среди ученых нет согласия относительно того, какие организмы (в том числе и животные) одушевлены, а какие остаются «бездушной физиологической машиной». Здесь А.И. в подстрочном примечании сослался на мнение Фехнера, что «особым сознанием» обладает каждый орган, организм, каждая планета и т.д.; упомянул он и фехнеровское противопоставление: die Tagesansicht gegenüber der Nachtansicht [16, c. 7].

Понятно, что имел в виду Введенский. Где-то в 70-х годах прошлого века одному из авторов этой статьи довелось ближе познакомиться с фигурой Густава Теодора Фехнера (18011887). Это был замечательный мыслитель - физик, философ, психолог, труды которого положили начало экспериментальной психологии (достаточно вспомнить закон Вебера - Фехнера о логарифмической связи между величиной раздражителя и силой вызываемого им ощущения). Ординарный профессор физики Лейпцигского университета, он переутомился, проводя свои исследования, и психика его пошатнулась. Он почти ослеп, часами пребывал в затемненном помещении. Но однажды, во время 
прогулки по саду, произошло исцеление, и он стал не просто видеть окружающие его вещи, но и приобрел дар восприятия душ растений. Дальнейшее развитие его «визионерской» способности привело его к убеждению, что вся природа, весь мир одухотворен. Тогда-то он и стал противопоставлять господствовавшему в его время взгляду на мир, который он уподоблял ночной мгле (die Nachtansich), - развивавшийся им светлый взгляд на мир (die Tagesansicht) ${ }^{19}$.

Рассматривая поднятый вопрос совершенно независимо от метафизических предположений и ограничиваясь в своих рассуждениях только тем, что может быть проверено «внутренним и внешним опытом», и ничего не принимая без такой «фактической проверки», Введенский следующим образом передает свой «психо-физический закон». Мы читаем:

Телесная жизнь, насколько она доступна эмпирическому познанию, всегда бывает такой, что все равно, сопровождается ли она душевной жизнью или нет $<\ldots>$ Из этого закона с необходимостью вытекает, что нет ни одного телесного явления, которое могло бы служить признаком одушевления. $<\ldots>$ А поэтому этот закон может быть назван законом отсутствия обгективных признаков одушевления. Ему-то и подчиняется всякая душевная жизнь. Такова проводимая нами мысль [16, с. 30] $]^{20}$.

А.И. Введенский отстаивал взгляд, что для того, чтобы основные законы связи душевных явлений с телесными можно было распространить на любую психическую («душевную») жизнь, в ком бы она ни проявлялась, нет никакой надобности в поисках объективных признаков одушевления. Он утверждал, что, не

\footnotetext{
${ }^{19}$ Психологи XIX-XX веков, разумеется, не приняли его взглядов, и в статье немецкого психолога Вильгельма Вундта, опубликованной к столетию со дня рождения Фехнера, говорится только о его экспериментальнопсихологических работах, но его «панпсихическое» учение замалчивается [30].

${ }^{20}$ Здесь стоит сказать, что Н.О. Лосский, оппонент Введенского (о дискуссии между Лосским и Введенским у нас еще пойдет речь) в своем труде «Чувственная, интеллектуальная и мистическая интуиция» [23] назвал это исследование А.И. Введенского замечательным.
} 
опасаясь ни противоречия с данными опыта, ни теоретического опровержения, можно как утверждать всеобщее одухотворение, так и отвергать любые формы психики - вопрос о пределах одушевления принадлежит к числу теоретически неразрешимых. Он рассуждал так.

Пусть признано, что психическое явление $a$ всегда сопровождается физиологическим явлением $a_{1}$, психическое явление $b-$ физиологическим явлением $b_{1}$, психическое явление $c-$ физиологическим явлением $c_{1}$, и т.д.; словом, каждое психическое явление сопровождается каким-нибудь физиологическим. Но ведь между «душевным» явлением $a$ и сопутствующим ему физиологическим явлением $a_{1}$ нет никакой логически обосновываемой связи, так как мы не вправе говорить, что $a_{1}$ есть причина, порождающая существование $a$, или наоборот $a$ есть причина, порождающая $a_{1}$, или же, наконец, что $a$ и $a_{1}$ возникают одновременно, как порождение какой-то третьей причины (например, Бога, установившего между ними предустановленную гармонию, или же единой субстанции, которая и духовна, и материальна).

Далее, не выходя за пределы опыта, мы не можем ответить на вопрос, когда у носителя психических явлений возникает душевная жизнь. Вопрос о времени возникновения психики у живого существа неразрешим. Это трансцендентно-метафизическая задача; «с чисто эмпирической же точки зрения первый момент душевной жизни можно поместить куда угодно; и даже можно считать ее безначальной и предсуществующей телесному возникновению человека» [16, с. 67].

Нам, конечно, странно и как-то неловко признавать теоретическую неразрешимость вопроса о времени возникновения душевной жизни, писал А.И., но такого рода вывод напрашивается сам собой, если принять закон отсутствия объективных признаков одушевления. Поскольку же мы свыклись с положением о зависимости психики от нервной системы, мы склонны допускать некоторый предел времени, раньше которого не может возникать душевная жизнь. Тут, однако, обнаруживается та трудность, что у простейших организмов, например амеб, нет нервной системы, и тем не менее у них наблюдаются явления (например, целесообразные движения), однородные с теми, 
которые мы находим у животных, считающихся обладающими психикой. Но между простейшими и высшими животными нет резкой границы, нет разделяющего их скачка.

До сих пор против рассуждений А.И. нечего возразить; более того, можно указать на ученых, высказывающих сходные мысли, и на факты, говорящие в пользу отстаиваемого Введенским «закона».

Среди ученых, пришедших к взглядам, сходных с теми, которые развивал Введенский, особенно выделяется Джон фон Нейман. В книге Б.В. Бирюкова о методологии науки, как она видится в свете кибернетики, обращено внимание на его воззрения относительно процесса субъективного восприятия. Рассматривая измерение физических величин, Нейман утверждал, что возникающий при этом процесс субъективного восприятия «выводит нас из внешнего физического мира или, точнее, вводит нас во внутреннюю жизнь индивидуума» [2]. Он указывал на

фундаментальное для всего естественнонаучного мировоззрения требование, так называемый принцип психофизического параллелизма, согласно которому должно быть возможно так описать в действительности внефизический процесс субъективного восприятия, как если бы он имел место в физическом мире, это значит сопоставить его последовательным этапам физические процессы в объективном внешнем мире, в обычном пространстве (естественно, что при этом процессе сопоставления <Zuordnungsprozess $>$ возникает еще необходимость локализовать эти физические процессы в таких точках, которые лежат в занимаемой нашим телом части пространства $[25]^{21}$.

Нейман привел пример. Пусть измеряется температура. Мы можем ограничиться визуальными показаниями термометра, но можем пойти дальше и определить длину его ртутного столба, сказав: вот длина, которую видит наблюдатель. Идя дальше, можно было учесть рассеяние световых квантов на непрозрачном столбике ртути вплоть до возникновения изображения на

\footnotetext{
${ }^{21}$ Вместо «Джона» его имя тогда читалось как «Иоганн», отсюда и соответствующий инициал.
} 
сетчатке глаза и только тогда сказать: это изображение регистрируется наблюдателем; наконец, если позволяют наши знания, мы могли бы пойти еще дальше и указать химические реакции, вызываемые этим изображением на сетчатке глаза, в нерве и в мозгу, и только тогда сказать: эти химические изменения воспринимаются наблюдателем. Это значит, утверждал Нейман, что мы всегда должны делить мир на две части - наблюдаемую систему и наблюдателя, причем положение границы между ними в высокой степени произвольно. «То, что такую границу можно переместить сколь угодно далеко внутрь организма действительного наблюдателя, и составляет содержание принципа психофизического параллелизма» [25, с. 308].

Из этих слов явствует, что содержание того, что воспринимается наблюдателем, все время остается от него скрыто; здесь происходит как бы «обращение» рассуждений Введенского об отсутствии объективных признаков психики, или душевных явлений. Только в отличие от русского философа фон Нейман начинает не с переживаний субъекта, а с физических процессов, которые для него не были «вещами в себе».

Теперь о фактах, подтверждающих позицию Введенского. Их можно извлечь из ведущихся ныне обсуждений вопроса, с какого момента можно считать, что возник организм, обладающий психикой. С момента рождения? Или во чреве матери? Или с момента слияния женской и мужской половых клеток? Эти вопросы актуальны в свете споров относительно того, с какого момента этически непозволительно смотреть на плод матери как на возможный источник стволовых клеток. Напомню, что православная Церковь считает: личность возникает в момент зачатия.

В завершение этой темы - недоступности чужой душевной жизни - отметим, что в отечественном умозрении она была с полной ясностью выражена гениальным Тютчевым. Как сказал он в стихотворении «Silentium»:

Как сердцу высказать себя?

Другому как понять тебя?

Поймет ли он, чем ты живешь?

Мысль изреченная есть ложь. 
Вернемся, однако, к Введенскому и укажем на один пункт в его рассуждениях, с которым трудно согласиться. По его мнению, для всякого, кто признал закон отсутствия объективных признаков психики и в то же время считает неоспоримой истиной одушевление других людей, логически неизбежен вывод о существовании особого (кроме эмпирических чувств и ума) органа метафизического познания; орган этот, будто бы, выводит нашу мысль за пределы всякого возможного опыта [16, с. 83]. Излишне, пожалуй, говорить, что такого органа до сих пор никто не обнаружил.. .

$$
* * *
$$

Перейдем теперь к работе Введенского о свободе воли. Автор начал с того, что уточнил смысл используемых им понятий детерминизма, индетерминизма и фатализма.

Учение, отрицающее существование хотя бы самой ограниченной свободы, называется детерминизмом. Учение же, допускающее хотя бы самую ограниченную свободу, лишь бы в смысле независимости от всяких причин, называется индетерминизмом $<\ldots>$ Фатализм учит $<\ldots>$ о независимости хода (важнейших - по крайней мере) событий от человеческой воли [18, с. 323].

Спор о свободе воли Введенский рассматривал в свете альтернативы «детерминизм - индетерминизм». Детерминизм не отрицает зависимости хода событий от нашей воли, «но уверен, что сами-то наши решения всегда сполна зависят от какихнибудь причин» $[18$, с. 324]. Поэтому не следует думать, что если мы опровергнем фатализм, то этим докажем свободу воли.

Можно было бы думать, что вопрос о свободе воли носит психологический характер. Но это не так: согласно Введенскому он относится к гносеологии. «Что касается психологии, то взятая сама по себе, без теории познания, она совершенно не в силах решить вопрос о свободе воли» [18, с. 326]. Но если доказать свободу воли психологическим путем невозможно, не следует ли из 
этого ее отсутствие? Нет, отвечает Введенский. Следует только то, что нам неизвестно, свободна воля или нет.

Но может быть решение вопроса дает ссылка на закон причинности? Привлекая его, кажется, что спор решается в пользу детерминизма. Если нет ни одного явления без причины, то всякое решение воли должно «сполна зависеть от обстоятельств, которые ему предшествуют и сопутствуют» [18, с. 331-332]. Однако имеет ли закон причинности всеобщее значение? Утвердительный ответ на этот вопрос подлежит доказательству, простая ссылка на него как на общепризнанную истину голословна.

Далее Введенский обратился к истории философии. Он констатировал, что и Аристотель, и Декарт, и Кант «защищают свободу воли, т.е. ее неполное подчинение закону причинности» [18, с. 331-332]; первый, кто поставил под сомнение вопрос, доказана ли всеобщность закона причинности, был Юм, который поэтому справедливо считается «предтечей критической теории познания» [18, с. 333].

После этого Введенский изложил свою позицию по данному вопросу. Он утверждал, что критическая теория познания не доказывает свободы воли, - она лишь дает возможность «с одинаковым правом и допускать, и отрицать ее, лишь оговариваясь, что и то, и другое предположение составит отнюдь не доказанное знание, а всего только неопровержимую при помощи знания и недоказуемую веру» $[18$, с. 338$]$.

И далее его рассуждения перешли в моральную плоскость. Он связал свободу воли с нравственным долгом, считая, что тот, кто в него верит, верит и в свободу воли; для него эта свобода проявляется «именно в том, что он признает безусловную обязательность нравственного долга и притом признает не на словах, а всем своим существом» [18, с. 359].

И заключительный аккорд:

существует ли свобода воли, этого мы не знаем и не можем знать $<\ldots>$ Но за то, благодаря критической философии, мы вот что знаем: 1$)<\ldots>$ всякое доказательство существования или отсутствия свободы воли составляет такое же мнимое, облыжное знание, как и решение квадратуры круга при помощи линейки и циркуля. 2) Если существует свобода воли (я 
говорю если), то ей не в чем состоять, как только в искреннем (не на словах, а всем существом) признании безусловно обязательного нравственного долга ${ }^{22}$ [18, c. 360].

Кантовско-критическая позиция Введенского, когда метафизика рассматривается как морально обоснованная вера, не могла не приводить его к конфронтации с атеистами и скептиками. Что касается философов-материалистов, то он не вступал с ними в споры, так как считал, что материализм как миросозерцание неопровержим. В связи с этим стоит сказать о его отношении к философским воззрениям Бенедикта Спинозы. Характерно уже название посвященной ему статьи - «Об атеизме в философии Спинозы» $[15]^{23}$.

Введенский рассматривает вопрос: «...нужно ли для Спинозы слово Бог, выражает ли оно у него какое-нибудь особое понятие, которое без этого термина осталось бы невыраженным» [15, с. 12] - и отвечает на него так: назвав субстанцию Богом, Спиноза не высказал о ней ровно ничего такого, чего он не высказал и что не могло бы быть им высказано о ней раньше [15, c. 15].

Рассматривая развитие философии Спинозы, Введенский утверждал, что в нем фигурирует только название Бог, а не понятие о нем, что название это используется им просто для обозначения субстанции. Без Бога он мог бы смело обойтись, и ко-

\footnotetext{
${ }^{22}$ Стоит сказать, что оппонент Введенского Н.О. Лосский занимал по данному вопросу совершенно другую позицию. Согласно его взгляду, пишет П.Гайденко, свобода воли означает, что все ее проявления могут определяться только ею самою. В этом смысле она есть causa sui - причина самой себя. Свобода воли есть как бы тот непробиваемый щит, которым человек надежно защищен от всяких причинных воздействий извне - от влияний чувственного мира, от воздействий других людей и даже от Бога, который не посягает на свободу воли человека. В соответствии с философской системой Лосского здесь следует говорить не только о человеке, но о «субстанциональном деятеле» вообе, ибо таковыми являются как разумные существа, так и бесчисленное множество не наделенных сознанием существ, расположенных в иерархическом порядке (см. [19, с. 359]).

${ }^{23}$ На титульной странице сказано: Оттиск из 37-й кн. «Вопросов философии и психологии».
} 
гда Спиноза называл субстанцию Богом, он, по словам А.И., «замаскировал пред самим собой атеизм своей философии» $[15$, с. 21].

Почему же Спиноза, не будучи в душе атеистом, пришел к атеистическому учению о мировой субстанции, ставит вопрос Введенский. И отвечает: в этом проявилось влияние философии Декарта, который стремился к тому, чтобы все реальные связи и взаимоотношения мыслились как логические. И Декарт, и Спиноза отождествляли причинную связь со связью логической со связью между основанием и следствием; оба они реальную независимость считали независимостью логической. Подобное отождествление реальных отношений с отношениями логическими, считал Введенский, вытекало из их механистического миросозерцания. Разница межу ними состояла только в том, что у Спинозы это миросозерцание было выражено гораздо сильней и более отчетливо, более осознанно, чем у Декарта.

Эта оценка философских взглядов Декарта и Спинозы, бесспорно, верна. Характеристика их воззрений как механистических («механических», как говорил А.И.) общепринята в современной философской историографии. Однако используемое Введенским понятие логического требует уточнения. «Логическое» и у Спинозы, и у Декарта не было таковым по существу. Это особенно видно в случае Декарта, который противопоставлял свои «правила для руководства ума» логической традиции, восходившей к философии эпохи схоластики. Это негативное отношение к логике в собственном смысле разделял и Спиноза, хотя он и строил свое главное сочинение «Этика» по образцу евклидовых «Начал».

Атеистичность философии Спинозы Введенский видел в том, что он не воспринимал события и процессы мира в понятиях целесообразности и целеполагания, т.е. не владел теми категориями, которые вывели бы его на понятие Бога. Вместо этого, писал А.И., у него наблюдается «уничтожение во вселенной действий по целям и объяснение всех фактов как неизбежных следствий из природы порождающих их субстанций» [15, с. 23].

Этот взгляд Введенского стоит сопоставить с трактовкой философии Спинозы главным советским «спинозоведом» Я. Миль- 
нером-Ирининым ${ }^{24}$. В отличие от Введенского у Мильнера акцент сделан не на атеизме Спинозы, а на его материализме. Но в остальном он солидарен с Введенским. Мильнер писал, что Спиноза «рассматривает бога, природу, субстанцию - все три слова едино суть - как существо, к сущности которого принадлежит существование, иными словами, как „саusa sui“», т.е. причину самой себя. И хотя Спиноза начинает свою «Этику» с учения «О боге», речь в ней идет (определение 1 части I) о том, сущность чего заключает в себе существование, иными словами о том, чья природа может быть представляема не иначе, как существующая [24, с. 62, 65-66].

Согласно Мильнеру, отход Спинозы от воззрений Декарта выразился в том, что картезианскому дуализму Спиноза противопоставил «материалистический монизм» и, следует добавить, атеизм. Но Введенский по-иному смотрел на философию той эпохи. Поставив вопрос, почему другие философские системы, возникшие под влиянием Декарта, - системы Гейлинкса, Мальбранша и Лейбница, не приняли атеистического характера, он дает на него следующий ответ. Ни одна из них не была чистым механицизмом. В окказионализме Гейлинкса и Мальбранша Бог «приноравливает свою деятельность к нашим хотениям, ибо действует по поводу них»; и действия эти рассматриваются как логически неизбежные [6].

Кроме того, у Мальбранша Бог творит мир, руководясь идеями, т.е. целями. У Лейбница же все мироздание в конце концов объясняется телеологически.

\footnotetext{
${ }^{24}$ Яков Абрамович Мильнер-Иринин (1911-1989) в 1933-1935 гг. в качестве научного сотрудника Ин-та философии Коммунистической академии работал над темой «Философия Спинозы». Перед войной с Германией вышла книга: Я. Мильнер «Бенедикт Спиноза» [24]. По этой книге МильнерИринин в 1943 г. защитил на философском факультете МГУ кандидатскую диссертацию. Будучи в 40-х годах старшим научным сотрудником Ин-та философии АН СССР, он подготовил докторскую диссертацию - «Понятие субстанции у Спинозы». Я.А. имел несчастье попасть в 1948 г. в кампанию против «безродных космополитов». Сохранились рукописи, в которых он продолжал анализировать учение Спинозы, и одна из них была напечатана уже после кончины автора, в 1999 г. См. статью о нем в кн. [1], написанную Н.Я. Ковановой (Мильнер), хранительницей архива Якова Абрамовича и, по-видимому, его дочерью.
} 
Таким образом, в их системах не было чистого механизма $^{25}$, т.е. не было причин, породивших атеизм в системе Спинозы, а потому не было и атеизма [15, c. 27-28].

\author{
$* * *$ \\ Заключительная часть статьи будет опубликована в следую- \\ щем выпуске.
}

\title{
Литература
}

[1] Алексеев П.В. Философы России XIX-XX столетий. Биографии, идеи, труды. М.: Академический проект, 2002.

[2] Бирюков Б.В. Кибернетика и методология науки. М.: Наука, 1974. С. 303.

[3] Бирюков Б.В. У истоков отечественных исследований по поиску логического вывода. О двух симпозиумах 60-х годов XX века, состоявшихся в г. Тракае (Литовская ССР) // Вопросы философии. 2006, № 12.

[4] Васильев Н.А. Логика и металогика // Логос. Кн. 1-2, 1912-1913.

[5] Введенский А.И. Вопросы философии и психологии. СПб., 1912.

[6] Введенский А.И. Декарт и окказионализм. Берлин - Пг. - М., 1922.

[7] Введенский А.И. Логика для гимназий. СПб., 1913.

[8] Введенский А.И. Логика, как часть теории познания. Второе, вполне переработанное, издание. СПб., 1912.

[9] Введенский А.И. Логика, как часть теории познания. Третье, вновь переработанное, издание. СПб., 1917.

[10] Введенский А.И. Логика, как часть теории познания. Четвертое издание, М.Пг., 1922 (на обложке - 1923).

[11] Введенский А.И. Научная деятельность М.И. Владиславлева // Журнал Министерства народного просвещения (ЖМНП). СПб., 1890, июнь м-ц.

[12] Введенский А.И. Новая постановка вопроса о самостоятельности четырех фигур силлогизма (из «commentationes philologicae»). СПб.: Типография Императорской Академии наук, 1897.

[13] Введенский А.И. Новое и легкое доказательство философского критицизма // Журнал Министерства народного просвещения (ЖМНП). Новая серия. Часть ХХ. СПб., 1909. Март. С. 122-144.

[14] Введенский А.И. Новое и легкое доказательство философского критицизма. СПб.: Сенатская типография, 1909.

[15] Введенский А.И. Об атеизме в философии Спинозы. М., 1897.

[16] Введенский А.И. О пределах и признаках одушевления. Новый психофизический закон в связи с вопросом о возможности метафизики. СПб., 1892.

[17] Введенский А.И. Психология без всякой метафизики. Пг., 1917.

[18] Введенский А.И. Спор о свободе воли перед судом критической философии // Журнал Министерства народного просвещения (ЖМНП). Седьмое десятилетие. Часть CCCXXXVII [337]. Октябрь 1901 г.

[19] Гайденко П.П. Иерархический персонализм Н.О. Лосского // Н.О. Лосский. Чувственная, интеллектуальная и мистическая интуиция. М., 1995.

\footnotetext{
${ }^{25}$ То есть механицизма.
} 
[20] Зенъковский В.В. История русской философии. Том II, ч. 1. Л.: Эго, 1991 [перепечатка издания: Ymca-Press. Париж, 1950].

[21] Карри Х.Б. Основания математической логики. Перев. с англ. В.В. Донченко. Под ред. Ю.А. Гастева. М.: Мир, 1969.

[22] Логика // БСЭ. 3-е издание. Том 14. 1962. С. 595-596.

[23] Лосский Н.О. Чувственная, интеллектуальная и мистическая интуиция. Париж, 1938.

[24] Милънер Я.А. Бенедикт Спиноза. [М.]: Соцэкгиз, 1940.

[25] фон Нейман И. Математические основы квантовой механики. Перев. с нем. М., 1964.

[26] Сербиненко В. Введенский Александр Иванович // Русская филсофия. Малый Энциклопедический словарь. М.: Наука, 1995.

[27] Смирнов В.А. Логические взгляды Н.А. Васильева // Очерки по истории логики в России. М., 1962.

[28] Финн В.К. Интеллектуальные системы и общество. М.: Издание Российского государственного гуманитарного ун-та, 2001.

[29] Челпанов Г.И. Учебник логики. Киев, 1897.

[30] Wundt W., Fechner W. Rede zur Feier seines hundertjähregen Geburtstages. Leipzig, 1901. 